\title{
The Influence of Supervisors' Leadership Style on Telecommuters
}

\author{
Paul E. Madlock \\ Texas A\&M International University • Laredo, TX
}

\begin{abstract}
The purpose of the current study was to extend prior scholarship by examining how employees who telecommute perceive their supervisor's leadership style and the subsequent outcomes. Specifically, the way in which leadership style influences employees' perceptions of their supervisors' communication competence and communication satisfaction with their supervisor. Employees' job satisfaction and organizational commitment was also assessed. Participants included 157 full time telecommuters from a variety of organizations across the United States. The findings suggest that supervisors in the virtual workplace engaged in task oriented more than relational oriented leadership style. Also, task oriented leadership served as the greatest predictor of the communication satisfaction, job satisfaction, and the organizational commitment of telecommuters. Recommendations for practitioners were also provided indicating that more might be done to enhance the task related leadership competencies of supervisors in the virtual work setting.
\end{abstract}

\section{Introduction}

The emergence of technology in the workplace has provided both large and small organizations with the ability to compete on a global scale, while at the same time, changed the way in which organizations interact and coordinate activities with customers, suppliers, and its members. These changes involve the substitution of everyday business activities which took place through face-to-face (FtF) interactions with electronic information exchanged through the use of computer technology (Straub \& Watson, 2001). Further, Herrmann (2006) argued that with the growth of computer technology in the workplace, mediated communication has become infused into nearly every business communication context. The introduction of computer technologies into the organizational context has also brought about a number of changes to both the organization and its members by altering core elements of the organization, such as its structure, culture, and performance (Jackson, Poole, \& Kuhn, 2002).

These technological advances have also allowed for a greater level of autonomy in the workplace, such as the ability to work away from the office. This work arrangement is being embraced by more and more companies who intend on capital- 
izing on the benefits of technology while minimizing costly resources such as office space (Wilkes, Frolick, \& Urwiler, 1994). This alternative form of work has historically been called telecommuting, telework, or virtual work, which is broadly defined as "working at one's home or another location where employees use computers and communication technology to communicate with the main office, supervisors, coworkers, and customers (Gibson, Blackwell, Dominicus, \& Demerath, 2002, p. 76). With over 20 million workers in the U.S. engaged in telecommuting and the number of telecommuters growing by over 20 percent annually, still very little is known about this increasingly popular work arrangement. One effect of this shift toward telecommuting is that leaders must assume more responsibility for working with followers who are at a distance (Antonakis \& Atwater, 2002; Bureau of Transportation Statistics, 2003; ITAC, 2000). According to Bass (1990) effective leadership "depends on physical proximity, social and organizational propinquity, and networks of open channels of communications" (p. 658). To date, much of the published leadership research has been situated in contexts where leader/follower interactions take place in traditional FtF work environments. Such research has demonstrated that leadership behaviors influence organizational performance, that strong leaders outperform weak leaders, and that relational oriented leadership style generates higher performance than does task oriented leadership (Bass, 1990; Madlock, 2010).

However, the lack of research in the virtual workplace has also raised questions about the performance implications of telecommuting (Neufeld \& Fang, 2005). Although, "leadership is enacted through communication" (Barge, 1994, p. 21), we still do not have a very clear understanding of how communication and leadership in the realm of telecommuting are related. Therefore, leadership researchers have called for developing an improved understanding of the links between leadership and communication (Conger \& Kanungo, 1988; Mumford et al., 2000). Effective leaders may tend to communicate using more metaphors, symbols, imagery and persuasive argumentation to sway others to accept their position (Bass, 1985). They may also engage in interpersonal communication to help followers understand their visions and strategies for action (Pondy, 1978).

Apart from a broad acknowledgement that leadership and communication seem to be conceptually related, there has been little empirical research explicitly examining leader communication effectiveness (Den Hartog \& Verburg, 1997). Thus, the objective of this paper is to improve our theoretical and practical understanding by engaging in a study of leadership and communication in the telecommuting setting. Specifically, the goal was to determine what form of leadership style (task and relational) and or communication behavior would elicit the most favorable 
outcomes in the realm of telecommuting. Therefore, the following section will offer additional support for the relevance of telecommuting research.

\section{Telecommuting}

Telecommuting has become increasingly popular because it gives employees increased flexibility in scheduling, less commuting time, and reduced work-family conflict and provides businesses with reduced real estate expenses and maintenance costs, increased productivity by employees, and access to global markets (Manochehri \& Pinkerton, 2003; Raghuram \& Wiesenfeld, 2004). As previously noted, improved productivity is probably the most widely touted benefit associated with telecommuting (Pinsonneault \& Boisvert, 2001). The primary explanation for this proposed advantage in performance is that doing tasks remotely also means fewer disruptions while working (Bailey \& Kurland, 2002). In addition to these benefits, the possible disadvantages associated with telecommuting include reduced communication with staff, feelings of isolation, decreased connectedness to the organization, and frustration at feeling 'out of the loop' in office politics (Gainey, Kelley, \& Hill, 1999; Wiesenfeld, Raghuram, \& Garud, 2001). Also, increased reliance upon electronic communication, such as email, may constrain the spontaneity and interactivity that typically take place with others in the office (Daft \& Lengel, 1986).

In response to these conflicting perspectives researchers have adopted Social Identity Theory and Social Isolation Theory to better explain the detrimental social consequences associated with telecommuting (Allen, Renn, \& Griffeth, 2003; Feldman \& Gainey, 1997). Similarly, scholars have commonly invoked media richness theory and social presence theory to predict reduced meaningfulness of relationships between telecommuters and their supervisors do to limitations found in computer mediated communication (CMC) (Daft \& Lengel, 1986; Short, Williams, \& Christie, 1976; Workman, Kahnweiler, \& Bommer, 2003). Unlike the theories previously referenced that portray technology as a barrier to effective communication between supervisors and telecommuters, Social Information Processing Theory (SIPT) appears to offer support for the use of technology as a viable means of communication between supervisors and telecommuters (Walther, 1992). Since leadership style is comprised of task and relational communication behaviors, SIPT served as a theoretical underpinning for the current study in order to better explain the possible use and impact of relational oriented messages from leaders in the virtual work setting. 


\section{Social Information Processing Theory}

According to SIPT, communicators often form impressions about others moods or state of mind despite the relatively limited nonverbal and physical cues available through mediated communication (Walther, 1992). In essence, SIPT rejects the view that the lack of physical cues limits individuals from effectively exchanging relational oriented information through computer technology. Walther (1992) argued that when denied these physical cues (e.g., nonverbal) that are available in $\mathrm{FtF}$ interactions, individuals sending and receiving messages via technology encode and decode relational messages using the cue systems that are available in the technology they are using. In sum, users of technology communicate in such a way that they exchange social information through the content, style, and timing of messages (Walther, 1992). In support of SIPT, several researchers have found that on-line relationships develop in a similar way as they do in the physical realm (Walther \& Boyd, 2002).

We know that in FtF interactions in traditional work settings leaders tended to use a relational oriented leadership style more than they used a task oriented style (Madlock, 2008). Further, it is also known that the use of relational oriented leadership style has a greater positive influence on the job satisfaction and commitment of workers than does task oriented leadership. However, we do not know which form of leadership style is most frequently used, or has the greatest influence on communication and organizational outcomes in the realm of telecommuting. Therefore, in order to better understand how supervisors effectively lead employees in the virtual workplace, leadership style will be considered in greater detail below.

\section{$\overline{\text { Leadership Style }}$}

Leadership has been defined in a number of ways, such as the ability to guide followers toward shared goals and as a form of influence (Bryman, 1992; Hersey, 1984). Pfeffer and Salancik (1975) indicated that effective leaders' tend to exhibit two distinct forms of communication (i.e., task and relational) when interaction with subordinates. In other words, leadership can be divided into task and relational oriented messages. The Ohio State and the Michigan studies were strong representatives of the styles approach. The Ohio State studies identified two types of behaviors explaining what leaders do: leaders provide structure and nurture subordinates (Hemphill \& Coons, 1957). At nearly the same time, the Michigan studies identified the behaviors of effective leaders to contain employee-oriented behaviors and production-oriented behaviors (Cartwrite \& Zander, 1960; Likert, 1961, 1967). 
Prior research indicates that leadership is enacted through communication and that it can be divided into the content of the message (task) and the presentation (relational dimension) of the messages (Barge, 1994; Holladay \& Coombs, 1993). Much of the published leadership literature research has been situated in traditional brick and mortar businesses. Research related to the styles approach to leadership indicated that relationship oriented leadership was displayed more frequently, preferred more often, and had a greater impact on employees' communication and job satisfaction than did task oriented leadership (Madlock, 2008). Additional research involving the effects of leadership style includes its relationship with group satisfaction, effective communication skills, interpersonal communication, and rapport building (Anderson, Madlock, \& Hoffman, 2006; Campbell, White, \& Johnson, 2003; Fairhurst, 1993; Mintzberg, 1994; Quick \& Macik-Frey, 2004). However, results may differ for close versus distant leader/follower relationships (Shamir, 1995).

Some prior research that has dealt with leadership in the virtual workplace has examined leadership impression management, leadership and communication effectiveness, and leadership performance appraisal (Conger \& Kanungo, 1988; Ferris et al., 1994; Neufeld, Wan, \& Fang, 2008). According to Conger and Kanungo (1998), the physical proximity to the leader to his or her followers may influence the importance of certain behavioral components in attributions of leadership effectiveness. Similarly, Shamir (1995) showed that rhetorical skills were more frequently attributed as an important characteristic of physically distant leaders, while being considerate of others and exhibiting unconventional behavior were more important attributions for close leaders.

Research has yet to fully examine the link between leadership style and communication in the realm of telecommuting. Based on what we do know, it could be extrapolated that when interacting with telecommuters the leadership style of supervisors and the associated outcomes may differ from those in traditional FtF work environments. From the foregoing one baseline research question was advanced:

Research Question 1: Which leadership style will be utilized most often by supervisors of telecommuters?

Communication is most effective when it leads to shared understanding and interpersonal communication skills are critical in determining whether a leader's message will be recalled and embraced (Conger \& Kanungo, 1998; Qureshi, Liu, \& Vogel, 2006). The most effective leaders interact and communicate with their followers frequently, fostering mutual trust, respect, and commitment between leader 
and followers (Uhl-Bien \& Graen, 1998). Effective leaders tend to craft their messages carefully, are open to followers' input, communicate candidly, and appeal to followers' aspirations in order to gain followers' trust and commitment (Bass, 1998). Leaders can also exercise their influence to motivate and inspire followers so as to draw them toward a shared understanding (Avolio, 1999). However, the connection between leadership style and communication competence has yet to be assessed in the virtual workplace and their association may differ from that of traditional work settings (Madlock, 2008). Given the task and relational component of communication competence its inclusion in the current study appeared warranted.

\section{Communication Competence}

Communication competence has been conceptualized "as a form of interpersonal influence in which an individual is faced with the task of fulfilling communication goals (effectiveness) while maintaining conversational and interpersonal norms (appropriateness)" (Spitzberg \& Cupach, 1981, p. 1). In following with this notion, communication competence has been conceptualized to encompass task related components, such as: knowledge and skill, as well as relational competencies, including: motivation, negotiation, and listening (Cushman \& Craig, 1976; Spitzberg, 1983). In a similar vein, Salacuse (2007) indicated that as a result of changing work environments in which employees are more educated and intelligent than past generations, leaders are now required to lead by negotiation. Specifically, Salacuse (2007) noted that in order for leaders to persuade people to follow their vision, they need to communicate effectively by appealing to the interests of the followers in order to sell their vision.

Leaders in a virtual work setting may have greater difficulty in achieving high levels of communication effectiveness. These leaders must rely more heavily on explicit task oriented communication, whereas leaders in traditional work settings may have at their disposal additional informal influence behaviors such as "standing on furniture" or "hanging ideas on clotheslines" (Jaussi \& Dionne, 2003, p. 475). Leaders and followers communicate and work synchronously and asynchronously through all kinds of information and communication technologies (e.g., e-mail, voice mail, video conferencing, and collaborative software systems), but technology mediated communication may be less effective in conveying social presence (Daft \& Lengel, 1986). This may be related to limited opportunities for interaction, reduced access to popular communication channels, time delays, and lack of shared language among diversified members (Powell, Piccoli, \& Ives, 2004). Therefore, distant lead- 
ers have to spend extra effort in converting and explicating what otherwise could be shared with ease through social presence in a physically proximate situation (Avolio $\&$ Kahai, 2003). Therefore, based on the limited amount of prior research, the following research question was advanced:

Research Question 2: Which form of leadership style displayed by supervisors in a virtual work setting will be the greatest predictor of their communication competence?

In the telecommuting setting there also appears to be a gap in the research examining supervisor task and relational oriented leadership and employee outcomes such as communication satisfaction. As a result, communication satisfaction was considered here and will be discussed in greater detail below.

\section{Communication Satisfaction}

Communication satisfaction in the workplace has been defined as satisfaction with various aspects of the communication that occurs in the organization, such as the amount and quality of information available (Crino \& White, 1981). Various studies highlighted the importance of communication on organizational success and have shown that communication quality is associated with employees' job satisfaction and motivation, job performance, productivity and organizational commitment (Clampit \& Downs, 1993; Gruneberg, 1979; Joshi \& Sharma, 1997; Orpen, 1997; Putti, Aryee, \& Phua, 1990). Research also indicated that employees who experience low levels of communication satisfaction experience reduced commitment, greater absenteeism and turnover, increased industrial unrest, and reduced productivity (Hargie, Tourish, \& Wilson, 2002). More recent research involving communication satisfaction indicated an association between supervisor leadership style and the communication satisfaction of their subordinates, with relational oriented leadership having a greater positive impact on the communication satisfaction of subordinates than did task oriented leadership (Madlock, 2008).

In the virtual work setting research indicated that as a result of lower social presence telecommuters experienced sharply diminished perceptions of intimacy and immediacy and a reduction in communication quality (Kurland \& Cooper, 2002; Short et al., 1976). However, there appears to be a lack of research involving leadership and communication satisfaction in the realm of telecommuting. Based on the nature of the telecommuting work environment, it could be extrapolated that the communication interactions between leaders and telecommuters may differ from those found in the traditional brick and mortar work setting. Coupled with the lack 
of prior research involving communication satisfaction in the virtual workplace, the following research question was advanced:

Research Question 3: Which behavior displayed by supervisors; task leadership style, relational leadership style, or communication competence, will serve as the greatest predictor of a telecommuter's communication satisfaction?

In addition to communication satisfaction, other outcomes of interest here include the job satisfaction and organizational commitment of telecommuters related to their supervisors' leadership style and communication competence. Therefore, the following section will highlight the value of job satisfaction and organizational commitment to the current study.

\section{Job Satisfaction and Organizational Commitment}

Job satisfaction has been defined as "a pleasurable or positive emotional state resulting from the appraisal of one's job or job experiences" (Locke, 1976, p. 1297). The most common factors leading to worker stress and dissatisfaction are those emanating from the nature of the job itself, within which interpersonal relationships between employees and management take place (Kenny \& Cooper, 2003). According to Korte and Wynne (1996), a deterioration of relationships in organizational settings resulting from reduced interpersonal communication between workers negatively influences job satisfaction, and sometimes leads to employees leaving their jobs.

Previous research in the traditional work setting has consistently demonstrated that work-related attitudes are important for individual performance as well as overall organizational productivity. Two specific groups of work related attitudes; job satisfaction and organizational commitment, have been examined for their relationship to the attitudes employees hold about their work and the organization (Miller \& Mange, 1986). While there has been considerable speculation as to the antecedent factors related to job satisfaction, its major effects on employees are quite clear. Low job satisfaction has been shown to be associated with high rates of absenteeism, tardiness, and turnover (Porter \& Steers, 1973).

While job satisfaction deals with a person's attitudes toward the job, organizational commitment addresses the person's attitudes toward the organization. Organizational commitment is characterized by a strong belief in and acceptance of the organization's goals and values, a willingness to exert considerable effort for the organization, and a desire to retain membership in the organization (Sager \& Johnston, 1989). Research has indicated positive relationships between organizational com- 
mitment and job satisfaction, job performance, and leadership (Bateman \& Strasser, 1984; Cohen, 1992; Morris \& Sherman, 1981). Prior research has also indicated that both job satisfaction and organizational commitment are directly related, in that the more satisfied employees are, the more committed to the organization they appear to be (Firth et al., 2004). More recently, Madlock (2008) found that both task and relational leadership styles had a positive influence on the job satisfaction and commitment of employees. In the realm of telecommuting, both job satisfaction and commitment have often been cited as advantages of telecommuting (Coveyduck, 1997; Pratt, 1999). Specifically, Coveyduck (1997) found that telecommuters derived relatively high level of job satisfaction, work autonomy, commitment, and feelings of organizational support. Tucker (1997) reported that telecommuters had high levels of job satisfaction and Hill (1995) found that productivity, morale, and organizational commitment were positively influenced by telework.

Despite the positive association between telecommuting and job satisfaction and commitment, there has been a lack of research examining the influence of leadership on these outcomes. However, Gibson et al. (2002) did suggest that situational leadership could be applicable to the virtual workplace and may produce similar positive outcomes as it has in traditional work settings. It was further argued that this type of leadership would make telecommuters feel comfortable and connected which could be linked to their job satisfaction and retention (Gibson et al., 2002). Therefore, the following hypotheses and research questions were advanced:

Hypothesis 1: There will be a positive relationship between a supervisor's task and relational leadership style and their telecommuters'job satisfaction.

Hypothesis 2: There will be a positive relationship between a supervisor's task and relational leadership style and their telecommuters'organizational commitment.

Research Question 4: Which behavior displayed by a supervisor, task leadership, relational leadership, or communication competence, will serve as the greatest predictor of a telecommuter's job satisfaction?

Research Question 5: Which behavior displayed by a supervisor; task leadership, relational leadership, or communication competence, will serve as the greatest predictor of a telecommuter's organizational commitment? 


\section{Method}

\section{Participants and Procedures}

The data collection procedure followed that of (Hartman, Stoner, \& Arora, 1991). Based upon a review of the telecommuting literature 21 organizations believed to have telecommuting programs were contacted by the author for possible participation in this study. Of the organizations contacted, seven agreed to participate in the current study. Participants included full-time non-management employees working for companies with established telecommuting programs in which employees worked from home using technology (i.e., telecommuters) to conduct business and communicate with their supervisors. The organizations that agreed to participate in the study either distributed copies of the questionnaire, allowed the author to distribute copies of the questionnaire, or made copies of the questionnaire available to employees on a volunteer basis. Respondents mailed completed questionnaires to the author. Based on distributions of questionnaires and on reports from site managers, approximately 400 telecommuters were invited to participate in the study; 157 telecommuters (approximately 39.2\%) provided useable completed surveys. Participants were comprised of ( $48 \%$ female, $n=85)$ and ( $52 \%$ male, $n=92$ ), whose overall tenure at their current job ranged from 3 to 12 years $(M=7.65, S D=3.27)$. Participants ranged in age from 23 to $49(M=30.86, S D=6.59)$ and reported working for a variety of organizations including; insurance $(30.5 \%$, $n=54)$, healthcare $(26.5 \%, n=47)$, high tech $(26.0 \%, n=46)$, and banking/finance $(17 \%, n=30)$. Of the technology used, all of the participants reported using a combination of technologies when communicating with their supervisors. These technologies included the most frequently reported form being cell phones (Blackberry $\left.{ }^{\circledR}\right)(68 \%)$, followed by computers (desktop and laptop) (29\%), and landline telephones (3\%). The most prevalent forms of communication used were text message, instant message (IM), voice (primarily via cell phone), email, blogging, and video calls (e.g., Skype $\left.{ }^{\circledR}\right)$.

\section{Measures}

All measures used in this study were submitted to principal component factor analysis using Varimax rotation. Criteria for factor and item retention were: 1) eigenvalues greater than 1.0 for retained factors, 2) primary factor loadings of .60 or greater, 3 ) no secondary loadings exceeding .40,4) loading on a factor with a minimum of two items, and 5) theoretical interpretability (Comrey \& Lee, 1992). All the items for the following measures met the aforementioned criteria. 
Leadership style was measured by the 20-item Leadership Style Questionnaire developed by Northouse (2001). The instrument measures the task and relational leadership styles and, when summed, represents a general leadership profile. A 5-point Likert-type scale ( $1=$ strongly disagree to $5=$ strongly agree) was used in this study, which was the same as the original measure. Prior research reported scale reliabilities ranging from .92 to .95 (Anderson et al., 2006; Madlock, 2008). Cronbach's alpha for the current study found that task leadership style was .91 $(M=3.88, S D=.58)$, and relational leadership style was .92 $(M=2.6, S D=.56)$.

Communication competence was measured by the 12-item Communicator Competence Questionnaire developed by Monge et al. (1982). The items were measured on a 5-point Likert-type scale ranging from $(1=$ strongly disagree to 5 = strongly agree), which was the same as the original measure. Prior research reported scale reliability of .93 (Madlock, 2006a). Cronbach's alpha for the current study was .91 $(M=4.10, S D=.62)$.

Communication satisfaction was measured with the 19-item Interpersonal Communication Satisfaction Inventory (ICSI) developed by Hecht (1978). A 7-point Likert scale $(1=$ strongly disagree to $7=$ strongly agree $)$ was used here, which was the same as the original measure. A slight modification was made to the original scale with a lead in sentence (When communicating with my supervisor I feel...) preceding each statement. Prior studies reported reliabilities ranging from .72 to .93 and strong validity (Rubin, Palmgreen, \& Sypher, 1994). Cronbach's alpha for the current study was $.89(M=5.65, S D=1.67)$.

Job satisfaction was measured by the eight-item Abridged Job In General Scale (AJIG) (Russell et al., 2004). A 5-point Likert-type response format ( $1=$ strongly disagree to $5=$ strongly agree $)$ was used in the current study instead of the original scale formatting (i.e., using 0 for "no," 1 for "?" and 3 for "yes") to be consistent with other parts of the questionnaire. The scale is comprised of single word or short statements regarding an employee's overall perception of their job (e.g., Good, Better than most, Undesirable). Prior research used the modified scale formatting and the study indicated that the AJIG Scale had strong reliability with a Cronbach's coefficient alpha of .90 (Madlock, 2010). Cronbach's alpha for the current study was $.87(M=3.83, S D=.54)$.

Organizational commitment was measured with the 15-item Organizational Commitment Questionnaire (OCQ) (Mowday et al., 1979). The items were measured on a 5 -point Likert scale ranging from $(1=$ strongly disagree to $5=$ strongly agree), which was the same as the original measure. The scale is intended to measure employee attachment to the organization, for example, "I am proud to tell others that 
I am part of the organization". Prior research indicated scale reliability of .93 (Madlock, 2006b). Cronbach's alpha for the current study was $.90(M=3.81, S D=.53)$.

\section{Results}

Hypothesis One predicted there would be a positive relationship between the task and relational leadership style of supervisors and the job satisfaction of their telecommuters. Results of Pearson's correlational analysis showed that the data were consistent with the hypothesis by indicating a significant positive relationship between the variables. The strength of all the correlational relationships examined in this study were based on the guidelines set forth by Cohen (1988, pp. 77-81). Specifically, a strong relationship was indicated between telecommuters' job satisfaction and their supervisor's task oriented leadership style $(r=.65, p<.01)$ and a weak relationship with their supervisor's relational oriented leadership style $(r=.22$, $p<.01$ ) (see Table 1 for all the correlational results).

Hypothesis two predicted there would be a positive relationship between the task and relational oriented leadership style of supervisors and the organizational commitment of their telecommuters. Results of Pearson's correlational analysis showed that the data were consistent with the hypothesis by indicating a significant positive relationship between the variables. Specifically, a strong relationship was indicated between telecommuters' organizational commitment and their supervisor's task oriented leadership style $(r=.42, p<.01)$, whereas a weak relationship was indicated between telecommuters' organizational commitment and their supervisor's relational oriented leadership style $(r=.20, p<.05)$.

\section{Table 1}

\section{Pearson Correlations among Variables (Mean scores)}

\begin{tabular}{|c|c|c|c|c|c|c|}
\hline & 1 & 2 & 3 & 4 & 5 & 6 \\
\hline 1 Task Leadership &. & & & & & \\
\hline 2 Relational Leadership & .15 &.- & & & & \\
\hline 3 Job Satisfaction & $.65^{\star \star}$ & $.22^{\star \star}$ &.- & & & \\
\hline 4 Communication Satisfaction & $.58^{* *}$ & $.18^{*}$ & $.49^{\star \star}$ &.- & & \\
\hline 5 Communication Competence & $.31^{\star \star}$ & $.29^{\star \star}$ & $.42^{\star \star}$ & $.22^{\star \star}$ &.- & \\
\hline 7 Organizational Commitment & $.42^{\star \star}$ & $.20^{*}$ & $.32^{\star \star}$ & $.20^{\star}$ & $.36^{\star \star}$ & .- \\
\hline
\end{tabular}

Note: ${ }^{* *}$ statistically significant at $p<.001,{ }^{*}$ statistically significant at $p<.05$ 
Research question one sought to answer the question of which leadership style would be utilized most often by supervisors of telecommuters. Results indicated that supervisors engaged in greater task oriented leadership $(M=3.88, S D=.58)$ than they engaged in relational oriented leadership behaviors $(M=2.6, S D=.56)$.

Research question two sought to answer the question of which form of leadership style displayed by supervisors in a virtual work setting would be the greatest predictor of their communication competence. Using multiple regression, supervisor communication competence was regressed on a linear combination of the two predictor variables. Results indicated that $\left(R^{2}=.10\right) 10 \%$ of the variance in communication competence was accounted for by task oriented leadership style, $F(1,155)=$ $16.24, p<.001$, whereas $\left(R^{2}=.15\right), 15 \%$ of the variance in communication competence was accounted for by the model containing both task and relational leadership style, $F(2,154)=14.54, p<.001$. Overall, task oriented leadership style was found to be a greater predictor of communication competence, $\beta=.27, p<.001$, than was relational oriented leadership style $\beta=.25, p<.001$.

Research question three sought to answer the question of which behavior displayed by supervisors; task leadership style, relational leadership style, or communication competence, would serve as the greatest predictor of a telecommuter's communication satisfaction. Using multiple regression, communication satisfaction was regressed on a linear combination of the three predictor variables. Results indicated that $\left(R^{2}=.049\right) 4.9 \%$ of the variance in communication satisfaction was accounted for by a supervisor's communication competence, $F(1,155)=7.93$, $p<.01 ;\left(R^{2}=.063\right), 6.3 \%$ of the variance in communication satisfaction was accounted for by the model containing both communication competence and relational leadership style, $F(2,154)=5.19, p<.01 ;\left(R^{2}=.34\right), 34 \%$ of the variance in communication satisfaction was accounted for by the model containing communication competence, relational leadership style, and task leadership style, $F(3,153)=26.57$, $p<.001$. Overall, task oriented leadership style was found to be the greatest predictor of communication satisfaction, $\beta=.56, p<.001$, whereas communication competence $\beta=.02, p>.05$ and relational leadership style $\beta=.09, p>.05$ were not found to be a significant predictor of communication satisfaction. 
Table 2
Summary of Regression Analysis for
Variables Predicting Communication Competence

\begin{tabular}{lccc}
\hline & \multicolumn{3}{c}{ Communication Competence } \\
\cline { 2 - 4 } Predictor & B & SE B & $\beta$ \\
\hline Relational leadership style & .15 & .04 & $.25^{\star *}$ \\
Task leadership style & .29 & .08 & $.27^{\star *}$ \\
(Constant) & 2.60 & .32 & \\
& $F(2,154)=14.54, p<.001$ & \\
\hline
\end{tabular}

${ }^{*} p<.05 .{ }^{* *} p<.001$.

Research question four sought to answer the question of which behavior displayed by supervisors; task leadership style, relational leadership style, or communication competence, would serve as the greatest predictor of a telecommuter's job satisfaction. Using multiple regression, job satisfaction was regressed on a linear combination of the three predictor variables. Results indicated that $\left(R^{2}=.179\right) 17.9 \%$ of the variance in job satisfaction was accounted for by a supervisor's communication competence, $F(1,155)=33.74, p<.001 ;\left(R^{2}=.188\right), 18.8 \%$ of the variance in job satisfaction was accounted for by the model containing both communication competence and relational leadership style, $F(2,154)=17.80, p<.001 ;\left(R^{2}=.479\right)$, $47.9 \%$ of the variance in job satisfaction was accounted for by the model containing communication competence, relational leadership style, and task leadership style, $F(3,153)=46.84, p<.001$. Overall, task oriented leadership style was found to be a greater predictor of job satisfaction, $\beta=.57, p<.001$ than was communication competence, $\beta=.23, p<.001$. Relational oriented leadership style was not found to be a significant predictor of job satisfaction $\beta=.06, p>.05$.

Research question five sought to answer the question of which behavior displayed by supervisors; task leadership style, relational leadership style, or communication competence, would serve as the greatest predictor of a telecommuter's organizational commitment. Using multiple regression, organizational commitment was regressed on a linear combination of the three predictor variables. Results indicated that $\left(R^{2}=.130\right) 13 \%$ of the variance in organizational commitment was accounted for by a supervisor's communication competence, $F(1,155)=23.12, p<.001$; $\left(R^{2}=.140\right), 14 \%$ of the variance in organizational commitment was accounted for by the model containing both communication competence and relational leadership 
style, $F(2,154)=12.55, p<.001 ;\left(R^{2}=.239\right), 23.9 \%$ of the variance in organizational commitment was accounted for by the model containing communication competence, relational leadership style, and task leadership style, $F(3,153)=16.06$, $p<.001$. Overall, task oriented leadership style was found to be a greater predictor of organizational commitment, $\beta=.33, p<.001$ than was relational oriented leadership style, $\beta=.23, p<.001$. Relational oriented leadership style was not found to be a significant predictor of organizational commitment $\beta=.08, p>.05$.

Table 3

Summary of Regression Analysis for

Variables Predicting Job Satisfaction and Organizational Commitment

\begin{tabular}{llllllll}
\hline & \multicolumn{3}{c}{$\begin{array}{c}\text { Job } \\
\text { Satisfaction }\end{array}$} & \multicolumn{4}{c}{$\begin{array}{c}\text { Organizational } \\
\text { Commitment }\end{array}$} \\
\cline { 2 - 7 } Predictor & B & SE B & $\beta$ & B & SE B & $\beta$ \\
\hline Communication competence & .20 & .055 & $.23^{\star \star}$ & .20 & .07 & $.23^{\star}$ \\
Relational leadership style & .03 & .031 & .06 & .04 & .04 & .05 \\
Task leadership style & .53 & .03 & $.34^{\star \star}$ & .30 & .07 & $.33^{\star *}$ \\
(Constant) & .88 & .057 & & 1.72 & .31 & \\
& $F(3,153)=46.84, p<.001$ & & \\
& $F(3,153)=16.06, p<.001$ & & & \\
\hline
\end{tabular}

${ }^{*} p<.05 .{ }^{* *} p<.001$.

\section{Discussion}

Today, with the anyplace and anytime nature of mobile technology, telecommuting has become more common and a more important work arrangement for organizations, and that there will be well over 90 million of these technology mediated jobs in the U.S. by 2030 the study of telecommuters appears to be warranted (Wilkes et al., 1994). One effect of this shift toward virtual work arrangements is that leaders must assume more responsibility for working with followers who are at a distance and leaders may find it more difficult in achieving high levels of communication effectiveness (Antonakis \& Atwater, 2002; Bass, 1990). Thus, the objective of this paper is to improve our theoretical and practical understanding by engaging in a study of leadership and communication in the telecommuting setting. Specifically, the goal was to determine what form of leadership style (task and relational) and or 
communication behavior would elicit the most favorable outcomes in the realm of telecommuting.

The first finding of interest centers on the correlational findings, which indicate that there was a greater emphasis placed on task oriented leadership in the virtual workplace compared to traditional work settings. This may be the result of distant leaders having to rely more heavily on explicit communication, whereas leaders in traditional FtF work settings may have at their disposal additional informal influence (Jaussi \& Dionne, 2003). Leaders and followers communicate and work synchronously and asynchronously through all kinds of information and communication technologies (e.g., e-mail, voice mail, video conferencing, and collaborative software systems), but technology mediated communication may be less effective in conveying nuances of meaning that are essential to the development of interpersonal relationships (Kiesler et al., 1987). This may lead to a reduction in emotional tone and feeling being both expressed by the communicator and understood by the receiver (Kiesler et al., 1987). Therefore, distant leaders have to spend extra effort in converting and explicating what otherwise could be shared with ease through social presence in traditional work settings (Avolio \& Kahai, 2003). This finding may also shape the expectations of telecommuters to the extent that they do not expect relationship oriented communication when conversing with leaders because it is thought to be less possible, hence they evaluate their leaders in task terms because that is what is expected.

Although these findings appear to contradict SIPT, another interpretation centers on the nature of the telecommuting work environment (Walther, 1992). Meaning, that the kinds of work that can effectively done via technology are more heavily task oriented, therefore valued leadership is one that is focused on tasks. Therefore, communication in this technologically mediated environment lends itself to the exchange of task related information. It is also possible that employees who are effective and comfortable with this type of work are themselves more task-oriented and as a result, appreciate like-minded leadership. Not to discount relational oriented leadership, but it seems that in the realm of telecommuters, effective leadership style may be perceived differently than in traditional work settings.

Additional findings of interest that buttress with the correlational results were found in the regression models indicating that task oriented leadership style was a greater predictor of the communication satisfaction, job satisfaction, and commitment of telecommuters than was communication competence and relational oriented leadership. This finding again suggests that in order for supervisors to be perceived as effective leaders they must possess the knowledge and skills associated with the 
job in order to be able to communicate task relevant information to telecommuters. Lastly, as organizations and employees become increasingly dispersed, communication becomes the principal means by which individuals exercise leadership (Penley \& Hawkins, 1985). Since communication effectiveness has also been broadly linked with leadership effectiveness, it is possible that communication competence may be associated more with task oriented leadership in the virtual work setting than in the traditional work environment (Klauss \& Bass, 1982).

Based on the current findings recommendations for practitioners indicate that more might be done to enhance the task related competencies of supervisors in the realm of telecommuting. These recommendations include, additional training on task related competencies and how to effectively communicate task related knowledge to telecommuters through the use of technology. Supervisors also need to be aware that it is possible that telecommuters prefer task oriented leaders because of the limitations found in technology, the expectations of telecommuters, the nature of the telecommuting work environment being heavily task oriented, and that telecommuters themselves may be more task-oriented and appreciate like-minded leadership.

\section{Limitations and Future Directions}

Although the current study adds to our understanding of leadership and communication in the realm of telecommuting work it is not without limitations. In order to fully understand the impact of the current findings a qualitative study needs to be considered in which the researcher can ask probing questions to uncover nuances not found in a quantitative study. Another limitation found here involves a level of uncertainty about the amount of time telecommuters spent in the office. This information may indicate whether telecommuters who frequented the office felt more connected and satisfied than those telecommuters who rarely visited the office.

Another limitation connected to this study is that all the forms of technology were chained together as if they had the same characteristics of emotional tone. However, there are some differences in voice based on the form of technology used and with heavy and long term use (Walther, 1992). In order to tease out these possible differences in technology, future researchers may want to collect a larger sample and compare the leadership styles and communication of supervisors based on the form of technology used.

Given the relevance of telecommuting, there are a number of additional research directions that one could pursue. One possible direction centers on a dialogic approach to examine the communication interactions that take place between su- 
pervisors and telecommuters. This may allow researchers to better understand how and why specific communication behaviors shape the perceptions of telecommuters more than others. Further, a dialogic approach may also shed light on the reasons why task oriented leadership has such a positive impact on telecommuters and their work related outcomes. Another possible direction for future researchers involves cross-cultural studies of leadership and communication in the virtual workplace. Given, today's global economy, these research findings may prove to enhance leadership training programs.

\section{References}

Allen, D. G., Renn, R. W. \& Griffeth, R. W. (2003). The impact of telecommuting design on social systems, self-regulation, and role boundaries. In G. Ferris \& J. Martochhio (eds.), Research in personnel and human resources management (pp. 125-163). Boston: JAI Press.

Anderson, C. M., Madlock, P. E. \& Hoffman, P. (2006). Leadership, commitment, and attitudes as predictors of satisfaction in small task groups. Paper presented at the Central States Communication Association Convention, Indianapolis, IN.

Antonakis, J. \& Atwater, L. (2002). Leader distance: A review and proposed theory. Leadership Quarterly, 13, 673-704. doi:10.1016/S1048-9843(02)00155-8

Avolio, B. J. (1999). Full leadership development: Building the vital forces in organizations. Thousand Oaks, CA: Sage.

Avolio, B. J., \& Kahai, S. S. (2003). Adding the "e" to leadership: How it may impact your leadership. Organizational Dynamics, 31, 325. doi:10.1016/S00902616(02)00133-X

Bailey, D. E., \& Kurland, N. B. (2002). A review of telework research: Findings, new directions and lessons for the study of modern work. Journal of Organizational Behavior, 23, 383-400.

Barge, J. K. (1994). Leadership: Communication skills for organizations and groups. New York: St. Martin's Press.

Bass, B. M. (1985). Leadership and performance beyond expectations. New York: Free Press.

Bass, B. M. (1990) Bass \& Stogdill's handbook of leadership: Theory, research, and managerial applications. New York: Free Press.

Bass, B. (1998). Transformational leadership: Industrial, military, and educational impact. Mahwah, NJ: Erlbaum.

Bateman, T. S., \& Strasser, A. (1984). A longitudinal analysis of the antecedents of organizational commitment. Academy of Management Journal, 27, 95-112. 
Bryman, A. (1992). Charisma and leadership in organizations. London: Sage.

Bureau of Transportation Statistics. (2003). Omnibus household survey results (August). Washington: U.S. Government Printing Office.

Campbell, K. S., White, C. D., \& Johnson, D. E. (2003). Leader-member relations as a function of rapport management. Journal of Business Communication, 40, 170-194.

Cartwrite, D., \& Zander, A. (1960). Group dynamics-research and theory. Evanston, IL: Row Peterson.

Clampit, P. G., \& Downs, J. D. (1993). Employee perceptions of the relationship between communication and productivity: A field study. Journal of Business Communication, 30, 5-28.

Cohen, J. (1988). Statistical power analysis for the behavioral sciences (2nd Ed.). Hillsdale, NJ: Erlbaum.

Cohen, A. (1992). Antecedents of organizational commitment across occupational groups: A meta-analysis. Journal of Organizational Behavior, 13, 539-558.

Comrey, A. L., \& Lee, H. B. (1992). A first course in factor analysis (2nd Ed.). Hillsdale, NJ: Erlbaum.

Conger, J. A., \& Kanungo, R. N. (1988). Charismatic leadership: The elusive factor in organizational effectiveness. San Francisco: Jossey Bass Publishers.

Conger, J. A., \& Kanungo, R. N. (1998). Charismatic leadership in organizations. Thousand Oaks, CA: Sage.

Coveyduck, D. H. (1997). Investigation of selected factors on job satisfaction among telecommuters. Unpublished master's thesis, Carleton University, Ottawa, Ontario, Canada.

Crino, M. E., \& White, M. C. (1981). Satisfaction in communication: An examination of the Downs-Hazen measure. Psychological Reports, 49, 831-838.

Cushman, D. P., \& Craig, R. T. (1976). Communication systems: Interpersonal implications. In G. R. Miller (ed.), Exploration in interpersonal communication (pp. 37-58). Beverly Hills, CA: Sage.

Daft, R. L. \& Lengel, R. H. (1986). Organizational information requirements, media richness and structural design. Management Science, 32, 554-571.

Den Hartog, D. N. \& Verburg, R. M. (1997). Charisma and rhetoric: Communicative techniques of international business leaders. Leadership Quarterly, 8, 355-391. doi:10.1016/S1048-9843(97)90020-5

Fairhurst, G. T. (1993). The leader-member exchange patterns of women leaders in industry: A discourse analysis. Communication Monographs, 60, 321-351. 
Feldman, D. C., \& Gainey, T. W. (1997). Patterns of telecommuting and their consequences: Framing the research agenda. Human Resource Management Review, 7, 369-388.

Ferris, G. R., Judge, T. A., Rowland, K. M., \& Fitzgibbons, D. E. (1994). Subordinate influence and the performance evaluation process: Test of a model. Organizational Behavior and Human Decision Processes, 58, 101-135. doi:10.1006/ obhd.1994.1030

Firth, L., Mellor, D. J., Moore, K. A., \& Loquet, C. (2004). How can managers reduce employee intention to quit? Journal of Managerial Psychology, 19, 170187.

Gainey, T. W., Kelley, D. E., \& Hill, J. A. (1999). Telecommuting's impact on corporate culture and individual workers: Examining the effect of employee isolation. S.A.M. Advanced Management Journal, 64, 4-10.

Gibson, J., Blackwell, C., Dominicus, P. \& Demerath, N. (2002). Telecommuting in the 21 st century: Benefits, issues and a leadership model which will work. The Journal of Leadership Studies, 8, 75-86.

Gruneberg, M. M. (1979). Understanding job satisfaction. New York: John Wiley.

Hargie, O., Tourish, D., \& Wilson, N. (2002). Communication audits and the effects of increased information: A follow-up study. The Journal of Business Communication, 39, 414-436.

Hartman, H. I., Stoner, S. R., \& Arora, R. (1991). A. investigation of selected variables affecting telecommuting productivity and satisfaction. Journal of Business and Psychology, 6, 207-225.

Hecht, M. L. (1978). The conceptualization and measurement of interpersonal communication satisfaction. Human Communication Research, 4, 253-264.

Hemphill, J. K., \& Coons, A. E. (1957). Development of the leader behavior description questionnaire. In R. M. Stogdill \& A. E. Coons (eds.), Leader behavior: Its description and measurement (pp. 6-38). Columbus: The Ohio State University, Bureau of Business Research.

Herrmann, A. F. (2006). Stockholders in cyberspace: Weick's sensemaking online. Journal of Business Communication, 44, 13-35.

Hersey, P. (1984). The situational leader. Escondido, CA: Center for Leadership Studies.

Hersey, P., \& Blanchard, K. H. (1969). Management of Organizational BehaviorUtilizing Human Resources. New Jersey: Prentice Hall.

Hill, E. J. (1995). J. (1995). The perceived influence of mobile telework on aspects of work life and family life: An exploratory study [Abstract] (Doctoral Dissertation, Utah State University, 1995). ProQuest Digital Dissertation, AAT 9603489. 
Holladay, S. J., \& Coombs, W. T. (1993). Communication visions: An exploration of the role of delivery in the creation of leader charisma. Management Communication Quarterly, 6, 405-427.

International Telework Association and Council (ITAC). (2000). Telework America Report 2000.

Jackson, M. H., Poole, M. S., \& Kuhn, T. (2002). The social construction of technology and studies of the workplace. In L. Lievrouw \& S. Livingstone (eds.), The handbook of new media (pp. 236-253). London: Sage.

Joshi, R. J., \& Sharma, B. R. (1997). Determinant of managerial job satisfaction in a private organization. Indian Journal of Industrial Relations, 33, 101-110.

Jaussi, K. S., Dionne, S. D. (2003). Leading for creativity: The role of unconventional leader behavior. Leadership Quarterly, 14, 475. doi:10.1016/S10489843(03)00048-1

Kenny, D., \& Cooper, C. (2003). Introduction: Occupational stress and its management. International Journal of Stress Management, 10, 275-279.

Kiesler, S., Siegel, J., \& McGuire, T. W. (1987). Social psychological aspects of computer mediated communication. In K. Finnegan, R. Salamon, \& R. Thompson (eds.), Information technology: Social issues (pp. 290-306). Seven Oaks, UK: Hodder and Stoughton.

Korte, W. B., \& Wynne, R. (1996). Telework: Penetration, potential and practice in Europe. Amsterdam: Ohmsha Press.

Kurland, N. B., \& Cooper, C. D. (2002). Manager control and employee isolation in telecommuting environments. Journal of High Technology Management Research, 13, 107-126.

Likert, R. (1961). New patterns of management. New York: McGraw-Hill.

Likert, R. (1967). The human organization: Its management and value. New York: McGraw-Hill.

Locke, E. A. (1969). What is job satisfaction? Organizational Behavior and Human Performance, 4, 309-336.

Madlock, P. E. (2006a). Do differences in displays of nonverbal immediacy and communicator competence between male and female supervisors affect subordinates, job satisfaction. Ohio Communication Journal, 44, 61-78.

Madlock, P. E. (2006b, November). Supervisors' nonverbal immediacy behaviors and their relationship to subordinates' communication satisfaction, job satisfaction, and willingness to collaborate. Paper presented at the National Communication Association Convention, San Antonio, TX.

Madlock, P. E. (2008). The link between leadership style, communicator competence, and employee satisfaction. Journal of Business Communication, 45, 61-75. 
Madlock, P. E. (2010). The development of technological management model: A conceptualization of computer technology in the workplace. International Association for Technology, Education, and Development, 38, 4564-4576.

Manochehri, G. \& Pinkerton, T. (2003). Managing telecommuters: Opportunities and challenges. American Business Review, 21, 8-16.

Miller, K., \& Mange, P. R. (1986). Participation, satisfaction, and productivity: A meta- analytic review. Academy of Management Journal, 29, 727-753.

Mintzberg, H. (1994). Rounding out the manager's job. MIT Sloan Management Review, 36, 11-25.

Monge, P. R., Backman, S. G., Dillard, J. P., \& Eisenburg, E. M. (1982). Communicator competence in the workplace: Model testing and scale development. Communication Yearbook, 5, 505-528.

Morris, J. H., \& Sherman, J. D. (1981). Generalizability of an organizational commitment model. Academy of Management Journal, 24, 512-526.

Mowday, R. T., Steers, R. M., \& Porter, L. W. (1979). The measurement of organizational commitment. Journal of Vocational Behavior, 14, 234-247.

Mumford, M. D., Zaccaro, S. J., Harding, F. D., Jacobs, T. O., Fleishman, E. A. (2000). Leadership skills for a changing world: Solving complex social problems. Leadership Quarterly, 11, 11-35. doi:10.1016/S1048-9843(99)00041-7

Neufeld, D. \& Fang, Y. (2005). Individual, social and situational determinants of telecommuter productivity. Information Management, 42, 1037. doi:10.1016/j. im.2004.12.001

Nilles, J. M. (1976). The telecommunications-transportation tradeoff. New York: Wiley \& Sons.

Nilles, J. M. (1998). Managing telework: Options for managing the virtual workforce. New York: Wiley \& Sons.

Northouse, P. G. (2001). Leadership: Theory and practice (2nd ed.). Thousand Oaks, CA: Sage.

Orpen, C. (1997). The interactive effects of communication quality and job involvement on managerial job satisfaction and work motivation. Journal of Psychology, 5, 121-125.

Penley, L. E. \& Hawkins, B. (1985). Studying interpersonal communication in organizations: A leadership application. Academy of Management Journal, 28, 309328. doi: $10.2307 / 256203$

Pfeffer, J., \& Salancik, G. R. (1975). Determinants of supervisory behavior: A role set analysis. Human Relations, 38, 138-153. 
Pinsonneault, A., \& Boisvert, M. (2001). The impacts of telecommuting on organizations and individuals: A review of the literature. In N. J. Johnson (ed.), Telecommuting and virtual offices: Issues and opportunities (pp. 163-185). Hershey, PA: Idea Group Publishing.

Pondy, L. (1978). Leadership as a language game. In M. C. W. McCall, \& M. M. Lombardo (eds.), Leadership: Where else can we go? (pp. 87-99). Durham, NC: Duke University Press.

Porter, L. W., \& Steers, R. M. (1973). Organizational, work, and personal factors in employee turnover and absenteeism. Psychological Bulletin, 80, 151-176.

Powell, A., Piccoli, G., \& Ives, B. (2004). Virtual teams: A review of the current literature and directions for future research. Database Advanced Information Systems, 35, 6-33.

Pratt, J. H. (1999). 1999 telework America national telework survey: Cost/benefits of teleworking to manage work/life responsibilities: The International Telework Association \& Council.

Putti, J. M., Aryee, S., \& Phua, J. (1990). Communication relationship satisfaction and organizational commitment. Group \& Organization Studies, 15, 44-52.

Quick, J. C., \& Macik-Frey, M. (2004). Behind the mask: Coaching through deep interpersonal communication. Consulting Psychology Journal: Practice and Research, 56, 67-74.

Qureshi, S., Liu, M., \& Vogel, D. (2006). The effects of electronic collaboration in distributed project management. Group Decision and Negotiation, 15, 55-75.

Raghuram, S., \& Wiesenfeld, B. (2004). Work-nonwork conflict and job stress among virtual workers. Human Resource Management, 43, 259-277.

Rubin, R. B., Palmgreen, P., \& Sypher, H. E. (1994). Communication research measures: A sourcebook. New York: Guilford.

Russell, S. S., Spitzmüller, C., Lin, L. F., Stanton, J. M., Smith, P. C., \& Ironson, G. H. (2004). Shorter can also be better: The abridged job in general scale. Educational and Psychological Measurement, 64, 878-893.

Sager, J. K., \& Johnston, M. W. (1989). Antecedents and outcomes of organizational commitment: A study of salespeople. Journal of Personal Selling \& Sales Management, 9, 30-41.

Salacuse, J. W. (2007). Real leaders negotiate. Harvard Management Update, 10, 2-3.

Shamir, B. (1995). Social distance and charisma: theoretical notes and an exploratory study. Leadership Quarterly, 6, 19-47. doi:10.1016/1048-9843(95)90003-9

Short, J. A., Williams, E., \& Christie, B. (1976). The social psychology of telecommunications. New York: Wiley. 
Spitzberg, B. H. (1983). Communication competence as knowledge, skill, and impression. Communication Education, 32, 323-329.

Spitzberg, B. H., \& Cupach, W. R. (1981, November). Self-monitoring and relational competence. Paper presented at the Speech Communication Association Convention, Anaheim, CA.

Straub, D. W., \& Watson, R. T. (2001). Research commentary: Transformational issues in researching IS and net-enabled organizations. Information Systems Research, 12, 337-345.

Uhl-Bien, M., \& Graen, G. B. (1998). Individual self-management: Analysis of professionals' self-managing activities in functional and cross-functional work teams. Academy of Management Journal, 41, 340-350. doi:10.2307/256912

Walther, J. B. (1992). Interpersonal effects in computer-mediated interaction: A relational perspective. Communication Research, 19, 52-91.

Walther, J. B., \& Boyd, S. (2002). Attraction to computer-mediated social support. In C. A. Lin \& D. Atkin (eds.), Communication technology and society: Audience adoption and uses, (pp. 153-188). Cresskill, NJ: Hampton Press.

Wiesenfeld, B. M., Raghuram, S., \& Garud, R. (1999). Communication patterns as determinants of organizational identification in a virtual organization. Organization Science, 10, 777-790.

Wilkes, R. R., Frolick, M. N., \& Urwiler, R. (1994). Critical issues in developing successful tele-work programs. Journal of Systems Management, 45, 28-34.

Wood, A. F., \& Smith, M. J. (2001). Online communication: Linking technology, identity, and culture. Mahwah, NJ: Erlbaum.

Workman, M., Kahnweiler, W., \& Bommer, W. (2003). The effects of cognitive style and media richness on commitment to telework and virtual teams. Journal of Vocational Behavior, 63, 199-219.

\section{Biographical Sketch of Author}

Paul Madlock Ph.D. is an Assistant Professor in the College of Business Administration at Texas A\&M International University. He has published numerous articles on technology, communication, leadership, and other management areas. 